\title{
Solar Reflectance Index of Pedestrian Pavements and Their Response to Aging
}

\author{
N. L. Alchapar, E. N. Correa, and M. A. Cantón
}

\begin{abstract}
Due to the impact of the optical characteristics of the materials composing the urban envelopes on the energy balance of cities, their categorization according to their ability to decrease urban temperatures is an indispensable tool for sustainable development. This work presents the evaluation results of the thermal performance of the different pedestrian pavements available in the region, so as to classify them according to the Solar Reflectance Index (SRI). The study was carried out during a 2-year period, involving the analysis of the behaviour of 28 pavements in widely used compositions, shapes and colours. Additionally, the aging effect of the material was quantified over the SRI. The results show that $74 \%$ of pavements diminished their initial ability for decreasing temperatures, while $50 \%$ of the dark material, with initial negative performances, improved their thermal behavior.
\end{abstract}

Index Terms-Aging, solar reflectance index, optical properties of materials.

\section{INTRODUCTION}

Just as materials have been traditionally characterized according to their mechanical, electrical or magnetic properties, this study proposes to characterize them according to their optical properties, expressed by means of the Solar Reflectance Index (SRI), in order to evaluate their energy-environmental behavior in an urban medium.

High Solar Reflectance Index (SRI) materials do not raise their temperature much when exposed to sun radiation. In cities, the use of cold materials is a passive cooling strategy appropriate for preventing excessive heat increase and accumulation. This also enables the improvement of urban space habitability in terms of comfort and decreasing the air-conditioning consumption in buildings, thus allowing a rational use of energy and contributing to environmental sustainability [3], [4], [8]. Albedo (â) and thermal emittance (ع) are important factors which affect the surface temperature of the material and the air temperature close to the surface. Surfaces with low solar reflectance absorb a greater fraction of incident solar energy [2], [5], [7], [9], [10].

A fraction of this energy goes into the ground and buildings, another fraction is transmitted by convection to the air (leading to an increase of air temperature), and the last one is radiated to the sky [1]. In equivalent conditions, a surface

Manuscript received October 30, 2012; revised December 30, 2012. This work was supported by the Agencia Nacional de Promoción Científica y Tecnológica -ANPCYT- (National Agency for Scientific and Technological Promotion) provided funds for the research. Also the Consejo Nacional de Investigaciones Científicas y Técnicas -CONICET- (National Council of Scientific and Technical Researches).

The authors are with the Institute of Environmental and Social Sciences (INCIHUSA)- Human Environment and Housing Laboratory. CONICET CCT-Mendoza. CC. Argentina (e-mail:nalchapar@mendoza-conicet.gob.ar, correa@mendoza-conicet.gob.ar macantón@mendoza-conicet.gob.ar). with less emissivity will radiate in less proportion and cool less, therefore presenting higher temperatures [2].

Thus the determination of solar reflectance, thermal emmitance $(\varepsilon)$ and the relative temperature of surfaces $(T s)$ with respect to the reference temperature of a black and white pattern (determined by the $S R I$ ) could help designers and consumers to choose adequate materials for energy consumption efficiency of buildings and communities.

\section{Methodology}

\section{A. Cases of Study}

The sample is made up of 38 pedestrian pavements frequently used in the local urban medium. The pavements were classified into four compositions: Monolayer (mono): Concrete and Natural Stone, and Bilayer (bi): Concrete-stone, and Concrete-calcareous.

TABLE I: MATERIAL CLASSIFICATION ACCORDING TO ITS COMPOSITION, COLOR AND TEXTURE.

\begin{tabular}{|c|c|c|c|c|}
\hline LAYER & COMPOSITION & $\mathrm{CO}$ & LOR & TEXTURE \\
\hline \multirow{2}{*}{ Mono } & Concrete & $\begin{array}{l}\text { Red } \\
\text { Yellow }\end{array}$ & $\begin{array}{l}\text { Gray } \\
\text { Black }\end{array}$ & Rustic \\
\hline & $\begin{array}{c}\text { Natural Stone } \\
600000^{\circ} 00^{\circ}\end{array}$ & \multirow{2}{*}{$\begin{array}{l}\text { Travertine } \\
\text { Red-multicolor } \\
\text { Bordeau } \\
\text { Jade Green }\end{array}$} & \multirow{2}{*}{$\begin{array}{l}\text { Gray-multicolor } \\
\text { Black-withe } \\
\text { Black-multicolor } \\
\text { Murcia Black }\end{array}$} & Smooth \\
\hline \multirow{2}{*}{$\mathrm{Bi}$} & $\begin{array}{c}\text { Concrete-stone } \\
000000000000 \\
\end{array}$ & & & $\begin{array}{l}\text { Rustic } \\
\text { Smooth }\end{array}$ \\
\hline & Concrete-calcareous & $\begin{array}{l}\text { Red } \\
\text { Yellow }\end{array}$ & Black & Smooth \\
\hline
\end{tabular}

TABLE II: MATERIAL CLASSIFICATION ACCORDING TO ITS SHAPE.

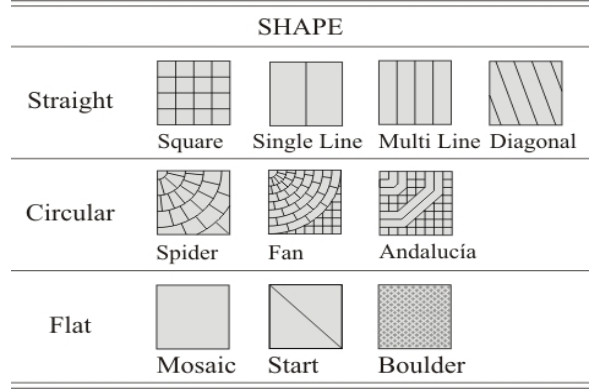

The monolayer (mono) compositions are pieces made up of only one material: concrete or natural stone. However, the bilayer (bi) materials are made up of a concrete-calcareous layer and a concrete-stone layer.

In Tables I y II pedestrian pavements are classified according to their composition, color, texture and shape.

\section{B. Experiment and Instrumentation Description}

To analyze the thermal behaviour of these samples, they were arranged on a $7 \mathrm{~cm}$ thick horizontal platform of expanded polystyrene located in the premises of the Centro Regional de Investigaciones Científicas y Técnicas, in 
Mendoza, Argentina.

The aging of the surfaces was estimated by registering the emissivity, surface temperature, solar radiation over horizontal surface and air temperature corresponding to 13.00 used to calculate the SRI according to the established regulations (ASTM E1980-11, 2011) [2].

The monitoring was carried out during the 2011 and 2012 summer seasons. Among the series of registered measurements, the data reported in this study corresponds to two days when meteorological variables present representative local climate conditions (March, 10th 2011 and February, 10th 2012). On March 10th, 2011 the registered sun radiation flux was $883.7 \mathrm{~W} / \mathrm{m} 2$, average air temperature $29.7^{\circ} \mathrm{C}$, relative humidity $24.5 \%$ and average wind speed $2.0 \mathrm{~m} / \mathrm{s}$. On February 10th, 2012 the registered sun radiation flux was $929.9 \mathrm{~W} / \mathrm{m} 2$, an average air temperature of $28.3^{\circ} \mathrm{C}, 31.5 \%$ of relative humidity and 1.3 $\mathrm{m} / \mathrm{s}$ of wind speed. In order to determine the value of albedo (â), a Kipp \& Zonen CMA11 albedometer was used. A temperature sensor with type $\mathrm{T}$ thermocouple associated with a U12 data logger hobbo was employed for the emissivity $(\varepsilon)$ calculations in accordance with regulations ASTM E-1933-99 ${ }^{a}$ [11], 2006. The surface thermal measurements (Ts) were taken with an IR Fluke Ti 55 camera (Table II).

\section{SRI Calculation}

The $S R I$ is a composite value in a scale from 0 to 100 based on the reflectance and emittance $(\varepsilon)$ of the material's surface. It is calculated using the equations in ASTM E1980-11 [12].

SRI quantifies the accumulated heat of material in relation to a black and white reference surface, under standard ambient conditions.

\section{Calculation of SRI Difference between 2011 - 2012 Thermal Registers}

In order to quantify the response of the thermal behavior of materials to aging, weather and dirt, the following formula was used:

$$
S R I_{2}-S R I_{1}=\Delta S R I
$$

where,

$S R I_{l}=$ initial Solar Reflectance Index;

$S R I_{2}=$ SRI of aged materials;

$\triangle S R I=$ Difference between $\mathrm{SRI}_{1}$ and $\mathrm{SRI}_{2}$ values .

To simplify the analysis a range of values was established to determine that the thermal behavior of material is stable when the $S R I$ differences are lower than $( \pm) 5 \%$ between both periods.

Aging is favorable when the initial $S R I\left(S R I_{l}\right)$ is lower than the aged material's $S R I\left(S R I_{2}\right)$. On the contrary, $S R I_{l}$ registers higher than $S R I_{2}$ were classified as materials whose ability to decrease urban temperatures falls when submitted to the passing of time, i.e. $\Delta S R I<-5 \%=$ Degraded; $\triangle S R I \leq( \pm)$ $5 \%=$ Stable $; \triangle S R I>5 \%=$ Improved .

\section{RESULTS}

The SRI for pedestrian pavements was obtained through the calculations made according to the ASTM E1980-11

equations and parameters. Under the analyzed conditions, new material (SRI), aged material (SRI2) and their corresponding differences $(\Delta \mathrm{SRI})$. (Table I y II).

TABLE III: Enumeration of Pedestrian Pavements Studied During THE First AND SECOND YeAR, with THEIR RESPeCTIVE AsSigned Codes; Albedo $(\hat{a})$, EMisSivity $(\varepsilon)$, SOLAR Reflectance IndeX $\left(S R I_{1}-S R I_{2}\right)$ IN PeRCENTAGES; AND SRI DifFERENCES $(\triangle S R I)$. (PART 1$)$

\begin{tabular}{|c|c|c|c|c|c|c|c|c|c|c|}
\hline \multirow[b]{2}{*}{ Cod. } & \multicolumn{2}{|c|}{ Layer } & \multirow[b]{2}{*}{ Description } & \multicolumn{3}{|c|}{$1^{\circ}$ Year } & \multicolumn{3}{|c|}{$2^{\circ}$ Year } & \multirow{2}{*}{$\begin{array}{c}\Delta \\
\text { SRI }\end{array}$} \\
\hline & Mono & $\mathrm{Bi}$ & & $\begin{array}{c}\mathrm{SRI}_{1} \\
\%\end{array}$ & â & $\varepsilon$ & $\begin{array}{c}\mathrm{SRI}_{2} \\
\%\end{array}$ & $\hat{\mathrm{a}}$ & $\varepsilon$ & \\
\hline$\overline{\text { P01 }}$ & $\mathrm{x}$ & & $\begin{array}{l}\text { Concrete gray } \\
\text { rustic circular fan }\end{array}$ & 71 & 0.54 & 0.90 & 60 & 0.48 & 0.90 & -11 \\
\hline P02 & $\mathrm{x}$ & & $\begin{array}{l}\text { Concrete black } \\
\text { rustic circular } \\
\text { spider }\end{array}$ & 59 & 0.42 & 0.95 & 59 & 0.45 & 0.95 & 0 \\
\hline P03 & $\mathrm{x}$ & & $\begin{array}{l}\text { Concrete red } \\
\text { rustic circular } \\
\text { andalucía }\end{array}$ & 77 & 0.59 & 0.95 & 59 & 0.45 & 0.95 & -18 \\
\hline P04 & $\mathrm{x}$ & & $\begin{array}{l}\text { Concrete red } \\
\text { rustic circular fan }\end{array}$ & 71 & 0.55 & 0.90 & 54 & 0.41 & 0.95 & -17 \\
\hline P05 & $\mathrm{x}$ & & $\begin{array}{l}\text { Concrete black } \\
\text { rustic circular fan }\end{array}$ & 52 & 0.35 & 0.95 & 51 & 0.38 & 0.95 & -1 \\
\hline P06 & & $\mathrm{x}$ & $\begin{array}{l}\text { Concrete-stone } \\
\text { gray rustic flat } \\
\text { boulder }\end{array}$ & 73 & 0.57 & 0.90 & 56 & 0.43 & 0.95 & -17 \\
\hline P07 & $\mathrm{x}$ & & $\begin{array}{l}\text { Concrete black } \\
\text { rustic straight } \\
\text { square }\end{array}$ & 55 & 0.39 & 0.95 & 51 & 0.38 & 0.95 & -4 \\
\hline P08 & $\mathrm{x}$ & & $\begin{array}{l}\text { Concrete gray } \\
\text { rustic circular } \\
\text { spider }\end{array}$ & 79 & 0.62 & 0.90 & 61 & 0.47 & 0.95 & -18 \\
\hline P09 & $\mathrm{x}$ & & $\begin{array}{l}\text { Concrete red } \\
\text { rustic circular } \\
\text { spider }\end{array}$ & 74 & 0.57 & 0.90 & 58 & 0.44 & 0.95 & -16 \\
\hline P10 & & $\mathrm{x}$ & $\begin{array}{l}\text { Concrete-stone } \\
\text { murcia black } \\
\text { smooth circular } \\
\text { fan }\end{array}$ & 53 & 0.36 & 0.95 & 48 & 0.35 & 0.95 & -5 \\
\hline P11 & & $\mathrm{x}$ & $\begin{array}{l}\text { Concrete-stone } \\
\text { black-white } \\
\text { smooth circular } \\
\text { andalucía }\end{array}$ & 72 & 0.56 & 0.90 & 57 & 0.43 & 0.95 & -15 \\
\hline P12 & & $\mathrm{x}$ & $\begin{array}{l}\text { Concrete-stone } \\
\text { murcia black } \\
\text { smooth straight } \\
\text { square }\end{array}$ & 54 & 0.38 & 0.95 & 56 & 0.42 & 0.95 & 2 \\
\hline P13 & & $\mathrm{x}$ & $\begin{array}{l}\text { Concrete-stone } \\
\text { gray-multicolor } \\
\text { smooth circular } \\
\text { andalucía }\end{array}$ & 80 & 0.64 & 0.85 & 64 & 0.50 & 0.95 & -16 \\
\hline P14 & $\mathrm{x}$ & & $\begin{array}{l}\text { Concrete yellow } \\
\text { rustic stright } \\
\text { diagonal }\end{array}$ & 71 & 0.55 & 0.90 & 61 & 0.47 & 0.95 & -11 \\
\hline P15 & $\mathrm{x}$ & & $\begin{array}{l}\text { Concrete red } \\
\text { rustic flat mosaic }\end{array}$ & 61 & 0.44 & 0.95 & 58 & 0.44 & 0.95 & -3 \\
\hline P16 & & $\mathrm{x}$ & $\begin{array}{l}\text { Concrete } \\
\text { multicolor rustic } \\
\text { flat boulder }\end{array}$ & 72 & 0.55 & 0.90 & 59 & 0.47 & 0.90 & -13 \\
\hline P17 & $\mathrm{x}$ & & $\begin{array}{l}\text { Concrete yellow } \\
\text { rustic flat start }\end{array}$ & 75 & 0.58 & 0.90 & 58 & 0.44 & 0.95 & -17 \\
\hline P18 & $\mathrm{x}$ & & $\begin{array}{l}\text { Concrete gray } \\
\text { rustic flat start }\end{array}$ & 73 & 0.56 & 0.90 & 55 & 0.41 & 0.95 & -18 \\
\hline P19 & $\mathrm{x}$ & & $\begin{array}{l}\text { Concrete black } \\
\text { rustic flat mosaic }\end{array}$ & 59 & 0.42 & 0.95 & 52 & 0.39 & 0.95 & -7 \\
\hline
\end{tabular}


(PART 2)

\begin{tabular}{|c|c|c|c|c|c|c|c|c|c|c|}
\hline \multirow[b]{2}{*}{ Cod. } & \multicolumn{2}{|c|}{ Layer } & \multirow[b]{2}{*}{ Description } & \multicolumn{3}{|c|}{$1^{\circ}$ Year } & \multicolumn{3}{|c|}{$2^{\circ}$ Year } & \multirow{2}{*}{$\begin{array}{c}\Delta \\
\text { SRI }\end{array}$} \\
\hline & Mono & $\mathrm{Bi}$ & & $\begin{array}{c}\mathrm{SRI}_{1} \\
\%\end{array}$ & $\hat{\mathrm{a}}$ & $\varepsilon$ & $\begin{array}{c}\mathrm{SRI}_{2} \\
\%\end{array}$ & $\hat{\mathrm{a}}$ & $\varepsilon$ & \\
\hline$\overline{P 20}$ & $\mathrm{x}$ & & $\begin{array}{l}\text { Concrete gray } \\
\text { rustic stright square }\end{array}$ & 77 & 0.60 & 0.90 & 60 & 0.46 & 0.95 & -17 \\
\hline P21 & & $\mathrm{x}$ & $\begin{array}{l}\text { Concrete-stone jade } \\
\text { green smooth } \\
\text { circular andalucía }\end{array}$ & 65 & 0.48 & 0.95 & 53 & 0.40 & 0.95 & -12 \\
\hline P22 & & $\mathrm{x}$ & $\begin{array}{l}\text { Concrete-stone } \\
\text { black-white smooth } \\
\text { straight square }\end{array}$ & 55 & 0.38 & 0.95 & 51 & 0.38 & 0.95 & -3 \\
\hline P23 & & $\mathrm{x}$ & $\begin{array}{l}\text { Concrete-stone } \\
\text { murcia black } \\
\text { smooth circular }\end{array}$ & 64 & 0.49 & 0.90 & 52 & 0.41 & 0.90 & -12 \\
\hline P24 & & $\mathrm{x}$ & $\begin{array}{l}\text { Concrete-stone } \\
\text { bordeau smooth } \\
\text { straight square }\end{array}$ & 72 & 0.56 & 0.90 & 55 & 0.41 & 0.95 & -17 \\
\hline P25 & $\mathrm{x}$ & & $\begin{array}{l}\text { Natural Stone gray } \\
\text { smooth flat mosaic }\end{array}$ & 85 & 0.68 & 0.85 & 66 & 0.53 & 0.90 & -18 \\
\hline P26 & & $\mathrm{x}$ & $\begin{array}{l}\text { Concrete-stone } \\
\text { black-multicolor } \\
\text { smooth circular } \\
\text { andalucía }\end{array}$ & 85 & 0.67 & 0.90 & 59 & 0.45 & 0.95 & -26 \\
\hline P27 & $\mathrm{x}$ & & $\begin{array}{l}\text { Concrete black } \\
\text { rustic circular } \\
\text { andalucía }\end{array}$ & 52 & 0.35 & 0.98 & 63 & 0.48 & 0.98 & 11 \\
\hline P28 & & $\mathrm{x}$ & $\begin{array}{l}\text { Concrete-stone red } \\
\text { smooth straight } \\
\text { square }\end{array}$ & 75 & 0.59 & 0.90 & 61 & 0.47 & 0.95 & -14 \\
\hline P29 & $\mathrm{x}$ & & $\begin{array}{l}\text { Natural Stone } \\
\text { murcia black } \\
\text { smooth flat mosaic }\end{array}$ & 62 & 0.47 & 0.90 & 54 & 0.42 & 0.90 & -8 \\
\hline P30 & & $\mathrm{x}$ & $\begin{array}{l}\text { Concrete-stone } \\
\text { gray-multicolor } \\
\text { smooth straight } \\
\text { square }\end{array}$ & 76 & 0.59 & 0.90 & 66 & 0.53 & 0.90 & -10 \\
\hline P31 & $\mathrm{x}$ & & $\begin{array}{l}\text { Natural Stone jade } \\
\text { green smooth flat } \\
\text { mosaic }\end{array}$ & 69 & 0.53 & 0.90 & 55 & 0.43 & 0.90 & -14 \\
\hline P32 & & $\mathrm{x}$ & $\begin{array}{l}\text { Concrete-stone jade } \\
\text { green smooth } \\
\text { straight square }\end{array}$ & 69 & 0.53 & 0.90 & 53 & 0.40 & 0.95 & -17 \\
\hline P33 & $\mathrm{x}$ & & $\begin{array}{l}\text { Concrete black } \\
\text { rustic straight } \\
\text { square }\end{array}$ & 59 & 0.43 & 0.95 & 55 & 0.42 & 0.95 & -4 \\
\hline P34 & $\mathrm{x}$ & & $\begin{array}{l}\text { Natural Stone } \\
\text { travertine smooth } \\
\text { flat mosaic }\end{array}$ & 100 & 0.93 & 0.80 & 100 & 0.82 & 0.80 & 0 \\
\hline P35 & & $\mathrm{x}$ & $\begin{array}{l}\text { Concrete- } \\
\text { calcareous black } \\
\text { smooth straight }\end{array}$ & 58 & 0.42 & 0.95 & 64 & 0.50 & 0.95 & 6 \\
\hline P36 & & $\mathrm{x}$ & $\begin{array}{l}\text { Concrete- } \\
\text { calcareous red }\end{array}$ & 72 & 0.56 & 0.90 & 56 & 0.42 & 0.95 & -17 \\
\hline P37 & & $x$ & $\begin{array}{l}\text { Concrete- } \\
\text { calcareous yellow } \\
\text { smooth straight } \\
\text { single line }\end{array}$ & 69 & 0.53 & 0.90 & 56 & 0.42 & 0.95 & -13 \\
\hline P38 & & $\mathrm{x}$ & $\begin{array}{l}\text { Concrete- } \\
\text { calcareous yellow } \\
\text { smooth stright } \\
\text { multi line }\end{array}$ & 74 & 0.58 & 0.90 & 55 & 0.42 & 0.95 & -19 \\
\hline
\end{tabular}

Initially the materials analyzed show higher dispersion in their SRI values, clearly identified with a cut line in SRI $=70 \%$. This means that $58 \%$ of the evaluated materials present an initial SRI in the $70-100 \%$ range, whereas the remaining $42 \%$ presents values between 69 and 50\% (Fig. 1).
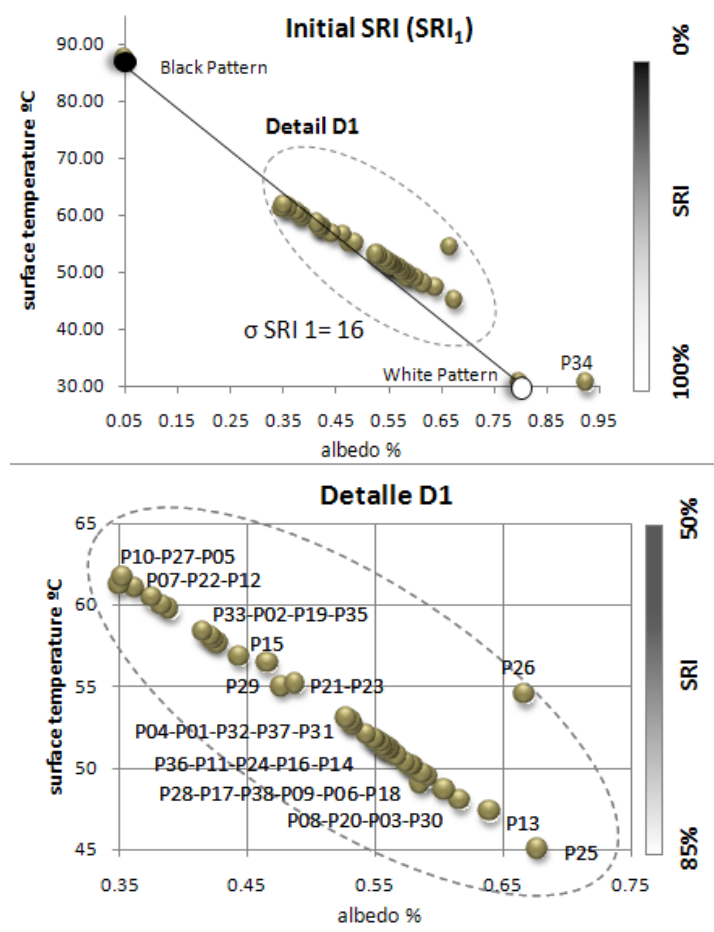

Fig. 1. Initial Solar reflectance index $\left(S R I_{1}\right)$ according to surface temperature $\left({ }^{\circ} \mathrm{C}\right)$ and albedo.

For aged materials $\left(S R I_{2}\right)$ the cut line disappears and all materials are grouped in a $66-48 \% S R I$ range, which indicates that over $58 \%$ of the materials initially evaluated were efficient in their thermal response, and their performance worsened in just one year by $24 \%$. Besides, it is clearly observable that the variable most affected by aging is albedo. Likewise, due to aging, surface temperatures in the studied cases had an approximate 7 to $11^{\circ} \mathrm{C}$ temperature increment. (Fig. 2 and Table III)
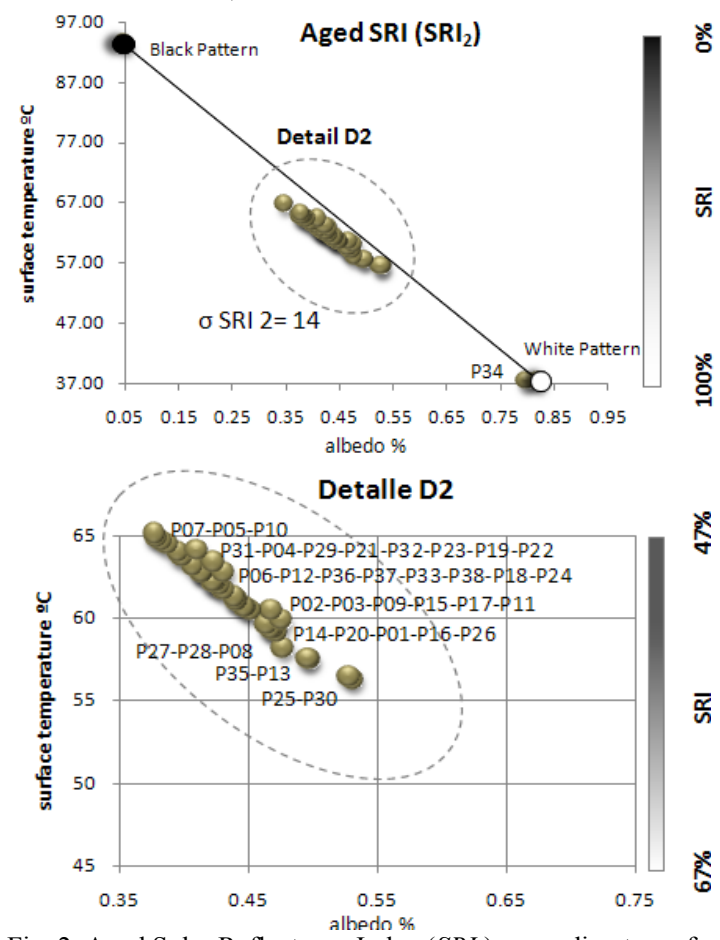

Fig. 2. Aged Solar Reflectance Index $\left(\mathrm{SRI}_{2}\right)$, according to surface temperature $\left({ }^{\circ} \mathrm{C}\right)$ and albedo. 


\section{A. Solar Reflectivity Index Aging according to its Composition}

After submitting the pavements to exterior weather conditions (aging), the SRI level differences were calculated for monolayer and bilayer materials. $70 \%$ of the monolayer materials and $78 \%$ of the bilayer decreased their thermal efficiency.

Within the stable materials there was $25 \%$ of monolayer and $11 \%$ of bilayer. Improvements of SRI higher to $15 \%$ were registered from which 5\% correspond to monolayer and $10 \%$ to bilayer. (Fig. 3. and Table III).

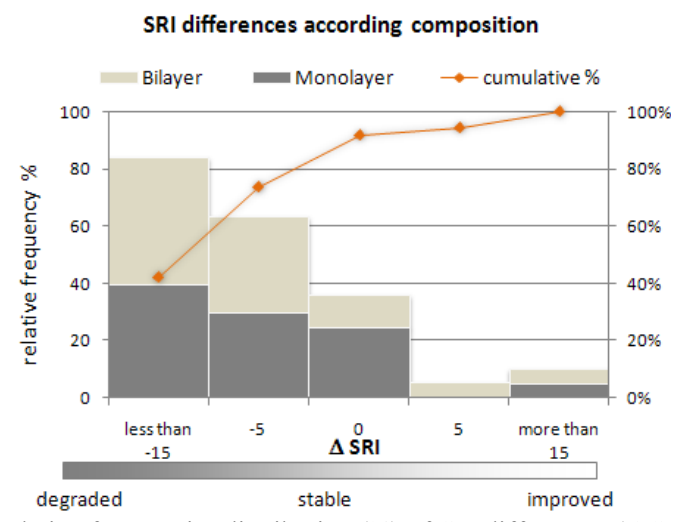

Fig. 3. Relative frequencies distribution (\%) of SRI differences $(\triangle S R I)$ in pedestrian pavements according to composition.

\section{B. Solar Reflectivity Index Aging According to its Shape}

By analyzing the materials in isolation and according to their shape, it was observed that the most thermally inefficient is the flat one. That means $90 \%$ of the materials with this configuration have decreased their SRI between 7 and $18 \%$.

The shapes that maintained their SRI stable to the passing of time, weather and dirt are the straight and circular, with a relative frequency of $21 \%$ in each case. $14 \%$ of straight pavements increased their SRI in a 5 to $15 \%$ range, improving their thermal conditions. (Fig. 4 and Table III).

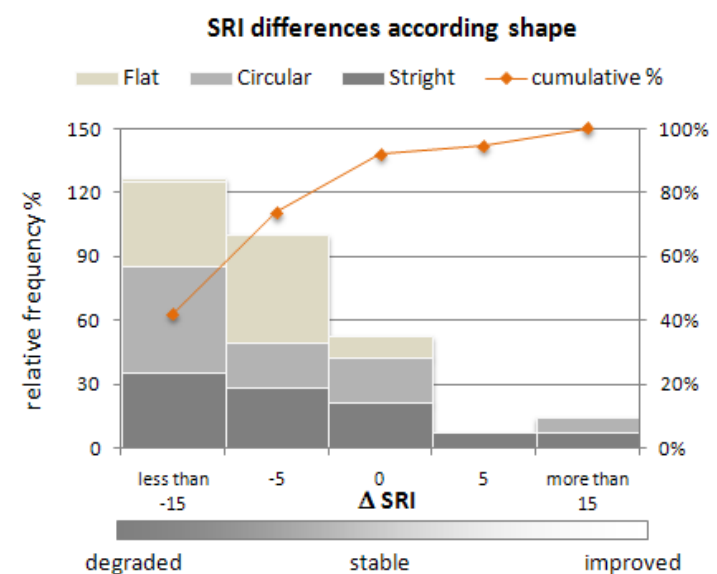

Fig. 4. Relative frequencies distribution (\%) of SRI differences ( $\triangle S R I)$ in pedestrian pavements according to shape.

\section{Solar Reflectivity Index Aging according to its Colors}

By separately analyzing the color variable for both compositions, we detected that $100 \%$ of the materials in gray, yellow, gray multicolor, travertine, red and black multicolor, and bordeau decreased their SRI by 5 to $20 \%$.
Within the colors that maintained a constant $S R I$ through time are, firstly, the black and black-white pavements, since half $(50 \%)$ the samples did not suffer wearing from open air exposure. Colors which increased the $S R I$ were black (27\%) and black-white (25\%) by 6 to $15 \%$. (Fig. 5 and Table III).

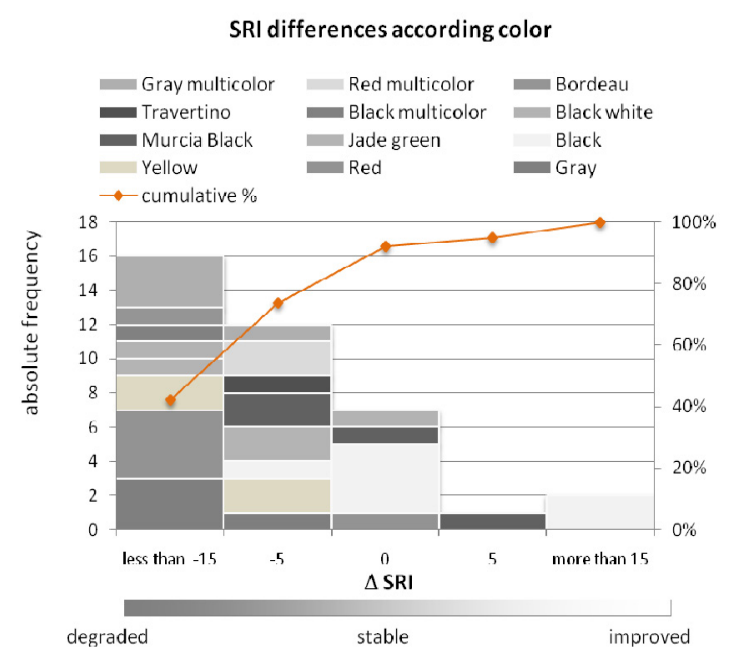

Fig. 5. Relative frequencies distribution (\%) of $S R I$ differences $(\triangle S R I)$ in pedestrian pavements according to color.

\section{CONCLUSION}

Results show that the SRI is a useful indicator for categorizing the thermal behavior of a group of pedestrian pavement samples. $74 \%$ of the pedestrian pavements tend to decrease their SRI with time as a consequence of the wearing away produced by exterior conditions and dirt accumulation.

The most affected optical property was albedo. However, a group of materials showed an improvement according to their classification: monolayer composition, straight shape and black and black-white color.

Finally, most of the evaluated pavements decreased their SRI by $23 \%$ in just a year in response to aging. Therefore it is necessary to quantify the indicator variation through time so as to achieve a rigorous characterization of the evaluated material's thermal behavior.

\section{REFERENCES}

[1] B. Givoni, Passive and Low Energy Cooling of Building, International Thomson Publishing, Inc. N.Y.: Wiley, 1994, pp. 1-36; 81-130.

[2] D. Sailor and H. Fan, "Modeling the diurnal variability of effective albedo for cities," Atmospheric Environment, vol. 36, pp. 713-725.

[3] G. Scudo and J. M. Ochoa, Spazi Verdi Urbani. La Vegetazione Come Strumento Di Progetto Per Il Comfort Ambientale Negli Spazi Abitati, Napoli: Sistemi Editoriali, 2003.

[4] H. Akbari, S. Davis, S. Dorsano, J. J. Huang, and S. Winert, Cooling our Communities- US Environmental Protection Agency, Office of Policy Analysis, Climate Change Division, 1992.

[5] J. Simpson and E. McPherson, "The effects of roof albedo modification on cooling loads of scale model residences in Tucson," Energy and Buildings, vol. 25. pp. 127-137, 1997.

[6] K. Niachou, L. Livada, and M. Santamouris, "Experimental study of temperature and airflow distribution inside and urban street canyon during hot summer weather conditions.-Part I: Air and surface temperatures," Building and Environment, vol. 43. pp. 1383-1392, 2008.

[7] M. Doulos, M. Santamouris, and I. Livada, "Passive Cooling of Outdoor urban spaces," The Role of Materials. Solar Energy, vol. 77. pp. 231-249, 2004.

[8] M. Santamouris, A. Synnefa, and Karlessi, "Using Advanced Cool Materials in the Urban Built Environment to Mitigate Heat Islands and 
Improve Thermal Comfort Conditions," Solar Energy, vol. 85, pp. 3085-3102, 2007.

[9] M. Santamouris, N. Papanikolaou, and C. Georgakis, "Internal Report. Group Building Environmental Studies, Physics Department," University of Athens, Athens, Greece, 1998.

[10] P. Araújo and F. Laurenco, "Measurement of Albedo and Analysis of Influence the Surfaace Temperature of Billding Roof Materials," Energy and Buildings, vol. 37. pp. 295-300, 2005.

[11] Standard Test Methods for Measuring and Compensating for Emissivity Using Infrared Imaging Radiometers, ASTM E-1933-99a. 2006.

[12] Standard Practice for Calculating Solar Reflectance Index of Horizontal and Low-Sloped Opaque Surfaces, ASTM E-1980-11. 2011.

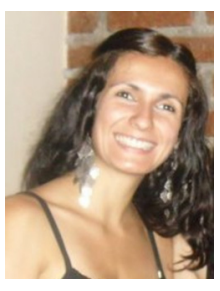

N. L. Alchapar is graduate Mendoza University, Facultad de Aquitectura y Urbanismo, Mendoza, Argentina in 2004. Currently, PhD student in Science area renewable energies - in the Salta National University of (UNSa), Salta, Argentina. Research fellow in the National Council of Scientific and Technological Research (CONICET) of Argentina, with place of work at the Laboratory for Human Environment and Housing (LAHV) of the Institute for Human, Social and Environmental Sciences (INCIHUSA-CONICET), in Mendoza, Argentina.

Her research focuses on the study of thermo-physical and optical properties of the materials of urban enveloping surface to mitigate the urban heat island. The main objective is to generate a valid tool to support decisions of urban design and sustainable building. The results have been published in national scientific journals and in proceedings of congresses on the subject.

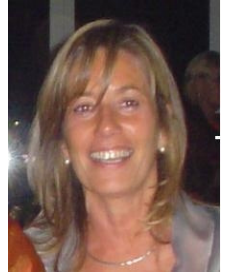

E. N. Correa is with Chemical Engineer $\mathrm{PhD}$ in Science - area renewable energy - (2006). Doctoral Thesis Subject: Urban Heat Island. The case of Mendoza Metropolitan Area. University Professor and Tenured Researcher in the National Council of Scientific and Technological Research (CONICET) of Argentina, with place of work at the Laboratory for Human Environment and Housing (LAHV) of the Institute for Human, Social and Environmental Sciences (INCIHUSA-CONICET), in Mendoza, Argentina. The research activity is focused on the study of the microclimatic effect or urban infrastructures along their entire life cycle in arid zones urban contexts. The main objective is to contribute to the sustainable urban planning and growth. On this theme, research projects have been financed by national and international agencies. The results have been published in national and international scientific journals and in proceedings of congresses on the subject.

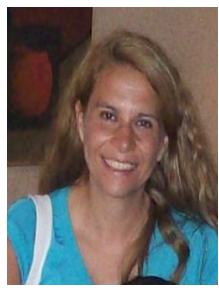

M. A. Cantón is with University Professor and Researcher in the National Council of Scientific and Technological Research (CONICET) of Argentina, with place of work at the Laboratory for Human Environment and Housing (LAHV) of the Institute for Human, Social and Environmental Sciences (INCIHUSA-CONICET), in Mendoza, Argentina.

The research activity is focused on the study of the open space as regulator of environmental conditions in arid zones urban contexts. The main objective is to conduct the urban and building development towards sustainability. On this theme, research projects have been financed by national agencies and by international cooperation. The results have been published in international scientific journals and in proceedings of congresses on the subject. 